Article

\title{
Application of Paclobutrazol to Mitigate Environmental Stress of Urban Street Trees
}

\author{
Bert Cregg ${ }^{1,2, *}$ and Dana Ellison-Smith ${ }^{1}$ \\ 1 Department of Horticulture, Michigan State University, East Lansing, MI 48824, USA; elliso52@msu.edu \\ 2 Department of Forestry, Michigan State University, East Lansing, MI 48824, USA \\ * Correspondence: cregg@msu.edu; Tel.: +1-517-353-0335
}

Received: 17 February 2020; Accepted: 19 March 2020; Published: 21 March 2020

\begin{abstract}
Paclobutrazol is a tree growth regulator that is frequently applied by arborists to control tree growth in utility rights of way. Paclobutrazol is also marketed to mitigate tree stresses associated with urban environments. In this study we applied paclobutrazol as a soil drench to honeylocust (Gleditsia triacanthos L var. inermis (L.) Zab.) and Callery pear (Pyrus calleryiana Decne.) trees planted as street trees on two sites in Lansing, Michigan USA. We evaluated physiological and morphological responses for two years after treatment. Application of paclobutrazol increased SPAD chlorophyll index of trees of both species in both years, compared to untreated control trees. Application of paclobutrazol increased leaf water potential of trees on one study site (Downtown) but not the other (Old Town). Paclobutrazol increased gas exchange (net photosynthesis and stomatal conductance) of Callery pear trees on one of four measurement dates (gas exchange was not measured on honeylocust trees). Leaf size of Callery pear trees was reduced following paclobutrazol application whereas leaf size of honeylocust trees was unaffected by paclobutrazol. These results indicate that paclobutrazol can help to reduce stress of trees and improve physiological function under urban conditions. However, paclobutrazol should be viewed as part of a suite of options for arborists and landscapers to manage trees on stressful sites, rather than as a replacement for proper overall care.
\end{abstract}

Keywords: tree growth regulators; plant water relations; SPAD index; gas exchange

\section{Introduction}

Paclobutrazol is a plant growth regulator that is increasingly used by arborists and landscapers to control height growth of landscape trees [1]. It inhibits gibberellin synthesis, reducing shoot elongation, resulting in shorter internodes [2] and is effective in reducing shoot growth on a range of tree species, though the effectiveness varies widely among species [1,3]. Paclobutrazol products currently labeled and marketed for arboricultural application include Cambistat ${ }^{\mathrm{TM}}$ (Rainbow Treecare Scientific Advancements), Profile ${ }^{\mathrm{TM}} 2 \mathrm{SC}$ (SePRO Corporation), and ShortStop®(Plant Growth Management Systems). Most of the formulations of paclobutrazol currently available for arboricultural use are designed to be applied via soil drench or soil injection, though formulations designed for foliar application are also available. Once in the soil, paclobutrazol is taken up by tree roots and translocated upward through the xylem to the growing points near the branch tips. Paclobutrazol is persistent within trees and within soil; therefore the effects of a single application can last 3 years or longer $[4,5]$.

In addition to controlling height and shoot growth, paclobutrazol can also affect a suite of morphological and physiological traits related to tolerance of a variety of environmental stresses [6]. Paclobutrazol increases the allocation of biomass to roots relative to shoots $[7,8]$. This increase in root:shoot ratio may be due to reduced shoot growth relative to roots or may be due to an absolute increase in root growth, especially fine roots near the soil surface [7]. Reductions in leaf growth associated with paclobutrazol application can be due to reduced leaf size as well as number of leaves 
produced [9-11]. Application of paclobutrazol can reduce tree water loss, resulting in improved tree water status based on reduced leaf area [12-14]. The production of smaller leaves and more compact tree crowns often results in increased foliar chlorophyll concentration (measured directly or through Soil Plant Analysis Development chlorophyll index (SPAD index)) and increased photosystem efficiency or photosynthetic rate [15-22]. Recent studies have also shown that paclobutrazol can enhance production of secondary pigments and molecules that can reduce the impacts of oxidative stresses such as drought or exposure to salinity [23,24]. Moreover, leaf micro-anatomy is affected by paclobutrazol application, including increases in palisade layer thickness and increased trichrome density, which are associated with increased drought tolerance [13,25].

Growth and physiological performance of street trees and other urban trees are often limited by a range of environmental stresses [26,27]. Urban stressors include below-ground factors such as poor soil conditions [28-30] or limited rooting volumes [31,32]. Urban trees are also subject to increased temperatures and vapor pressure deficits associated with urban heat island effects [33,34]. Due to the combination of above-ground and below-ground stresses, urban trees often have lower leaf water potentials and reduced rates of photosynthetic gas exchange compared to trees less developed or park-like settings [32,34]. Given that water stress is a common limiting factor for trees in landscapes and urban areas, application of paclobutrazol may be effective as a transplant aide or as a technique to mitigate urban stresses in existing street trees [7,35]. While the studies referenced above demonstrate numerous effects of paclobutrazol on physiology and morphology of trees, most studies of paclobutrazol on trees have been conducted under controlled conditions or with container-grown trees. Relatively few studies have considered whether stress mitigation effects of paclobutrazol application can be detected above the environmental noise of an urban street tree environment [7,8]. Aboveground and belowground environments in urban areas are often extremely heterogeneous and subject to anthropogenic factors $[28,33,34]$, which may confound treatment effects and reduce the likelihood of identifying a tree response to cultural treatments.

In this study, we investigated the effect of paclobutrazol on physiology and morphology of two common street tree species under typical urban conditions in Lansing, Michigan USA. The goal of the project was to determine if applying paclobutrazol could mitigate tree stress in a representative population of urban street trees. Our specific objectives were to determine whether soil-applied paclobutrazol affects leaf morphology, SPAD chlorophyll content index, photosynthetic gas exchange or leaf water potential of honeylocust (Gleditsia triacanthos L var. inermis (L.) Zab.) and Callery pear (Pyrus calleryiana Decne.) street trees.

\section{Materials and Methods}

\subsection{Study Sites}

The study was conducted in Lansing, Michigan, USA $\left(42^{\circ} 44^{\prime} \mathrm{N}, 84^{\circ} 32^{\prime} \mathrm{W}\right)$ (Figure 1$)$. According to the 2010 US census, the population of Lansing was 114,297. Lansing has a humid continental climate with cold winters (USDA Hardiness zone $5 \mathrm{~b}$, mean Jan. temperature $=-4.8^{\circ} \mathrm{C}$ ) and warm, humid summers (mean July temperature $=21.9{ }^{\circ} \mathrm{C}$ ). Average annual precipitation in Lansing is $900 \mathrm{~mm}$. Long-term average precipitation is evenly distributed throughout the year, but rainfall distribution and total rainfall can vary widely from year to year. 


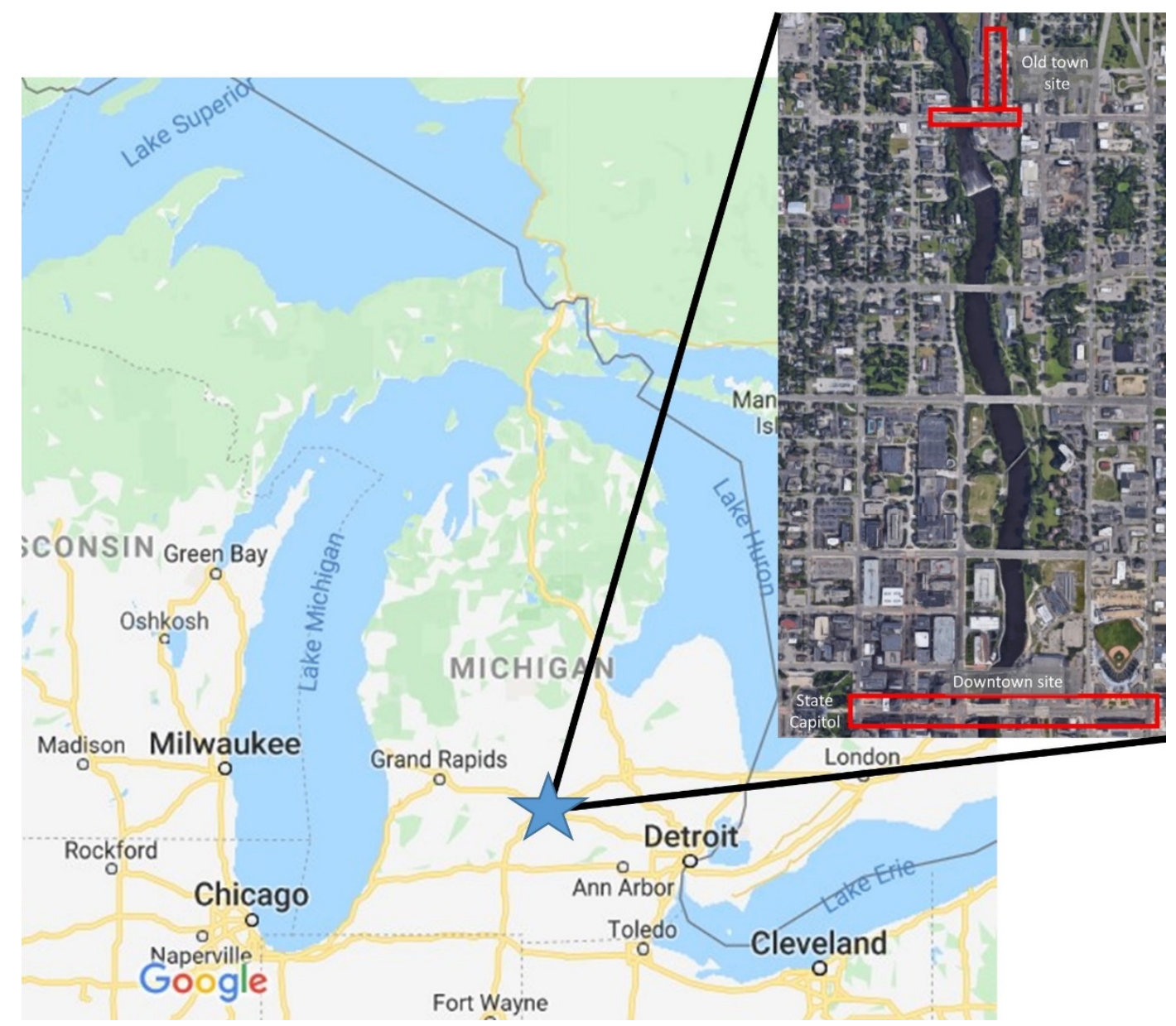

Figure 1. Location of field plots in Downtown and Old Town Lansing, MI, USA.

We identified trees for the study in cooperation with personnel from the city of Lansing. We selected honeylocust (Gleditsia triacanthos L var. inermis (L.) Zab.) and Callery pear (Pyrus calleryiana Decne.) trees for study because they are common throughout the city and are representative of trees planted in similar communities throughout the Midwestern USA. We selected trees in two areas within the city, Downtown and Old Town. Trees on the Downtown site were located along a single main street, Michigan Avenue, which runs east-to-west through the main downtown of Lansing. The Old Town site is located approximately $2 \mathrm{~km}$ north of the central downtown area. This site included trees along two streets, Turner Avenue, which runs north-to-south and Grand River Avenue, which runs east-to-west. Nearly all trees were located in tree pits between the sidewalk and the street. Typical pit dimensions were $1.3 \mathrm{~m} \times 1.3 \mathrm{~m}$. Four of the honeylocust trees on the north end of the Old Town site were located in tree lawns. Mean soil $\mathrm{pH}$ of the sites was 7.9. At each site we conducted an initial inventory of candidate trees for study. The dbh (diameter at breast height $-1.5 \mathrm{~m}$ ) and height of each tree was measured (Table 1).

Table 1. Mean dbh (diameter at breast height) and tree heights ( \pm std. err.) and sample size for honeylocust and Callery pear trees at two locations in Lansing, MI USA.

\begin{tabular}{ccccccc}
\hline & \multicolumn{4}{c}{ Downtown } & \multicolumn{3}{c}{ Old Town } \\
\cline { 2 - 7 } Species & $\mathbf{n}$ & Dbh $(\mathbf{c m})$ & Height $(\mathbf{m})$ & $\mathbf{n}$ & Dbh $\mathbf{( c m})$ & Height $(\mathbf{m})$ \\
\hline Honeylocust & 10 & $26.5 \pm 3.3$ & $7.84 \pm 0.19$ & 14 & $37.9 \pm 1.5$ & $13.01 \pm 0.38$ \\
Callery pear & 48 & $12.3 \pm 0.5$ & $5.70 \pm 0.18$ & 14 & $22.7 \pm 1.8$ & $9.04 \pm 0.57$ \\
\hline
\end{tabular}


Treatments were assigned to the trees using a paired plot approach. Trees were grouped by site, species, and aspect and then sorted by diameter. Trees of similar diameter were paired and one tree was selected at random to receive treatment with paclobutrazol, while the other tree served as an untreated control. We applied paclobutrazol treatments on June 23, 2013. All treatments were applied as a soil drench of Cambistat ${ }^{\mathrm{TM}}$ (22.3\% paclobutrazol a.i.) according to the product label. Ready-to-use (RTU) solution was produced by diluting concentrated product at a 1:11 ratio (concentrate: water, $\mathrm{v}: \mathrm{v})$. We applied RTU solution as a soil drench around the root flair of each tree. The solution was poured slowly around the base of each tree to ensure that the solution infiltrated the soil and did not run off. Application rates were based on the Cambistat ${ }^{\mathrm{TM}}$ product label; $1.1 \mathrm{~g}$ a.i per $\mathrm{cm}$ of $\mathrm{dbh}$ for the honeylocust trees and $1.5 \mathrm{~g}$ a.i. per $\mathrm{cm}$ of dbh for the Callery pear trees. We assessed the trees for evidence of potential phytotoxicity (e.g., leaf discoloration, anomalous growth) one month after application and observed no evidence of adverse effects.

\subsection{Measurements}

\subsubsection{SPAD Chlorophyll Index}

We assessed chlorophyll content index for all trees in July 2014 and 2015 using a SPAD chlorophyll meter (SPAD-501, Minolta, Inc.). For some of the Callery pear trees at the Downtown site, we were able to access sample leaves (2-2.5 $\mathrm{m}$ height) from the ground. For the remaining trees, shoots were clipped using a pole pruner from exposed branches (south or west side) from the mid-crown (3-7 m height). We measured SPAD index on five leaves per tree and recorded the average.

\subsubsection{Photosynthetic Gas Exchange}

We measured photosynthetic gas exchange of Callery pear trees at the Downtown site on two dates in 2014 (9 July and 6 Aug) and two dates in 2015 (6 Aug and 1 Sept) using a portable photosynthesis system (LI-6400, Li-Cor, Inc., Lincoln NE USA). We measured photosynthetic gas exchange on Callery pear trees only, as these trees have simple leaves that completely fill the leaf chamber of the LI-6400. We did not measure gas exchange on honeylocust trees due to difficulties of estimating leaf area in the leaf chamber of their pinnately compound leaves that have very small leaflets. Each set of gas exchange measurements was divided into a morning run and afternoon run. Morning measurements were completed between 9:00 and 12:00; afternoon measurements were completed between 13:00 and 16:00. A 10-15 cm shoot was clipped from each tree using a pole pruner for each gas exchange measurement. We placed one leaf, still attached to the shoot, into the Li-6400 leaf chamber. Preliminary testing indicated that gas exchange rates remain stable for at least 5 minutes after shoot removal under a range of environmental conditions. All gas exchange measurements were standardized using the control systems of the Li-6400 with a flow rate of $500 \mathrm{ml} \mathrm{min}^{-1}$, photosynthetically active radiation of $1500 \mathrm{~mol} \mathrm{~m}^{-2} \mathrm{~s}^{-1}$ and reference $\mathrm{CO}_{2}$ of $400 \mathrm{ppm}$. As recommended by the manufacturer, the desiccant column was set to slightly dry the air and all measurements were collected at ambient temperature. Mean ( \pm standard error) leaf temperature and vapor pressure deficit based on leaf temperature (VpdL) during the gas exchange measurements were: 9 July $2014=24.7( \pm 0.20){ }^{\circ} \mathrm{C}$ and $1.6( \pm 0.03) \mathrm{kPa}$; 6 Aug $2014=27.1( \pm 0.18)^{\circ} \mathrm{C}$ and $2.0( \pm 0.04) \mathrm{kPa} ; 6$ Aug $2015=28.4( \pm 0.22)^{\circ} \mathrm{C}$ and $2.0( \pm 0.04) \mathrm{kPa}$; 1 Sept $2015=32.5( \pm 0.16)^{\circ} \mathrm{C}$ and $1.9( \pm 0.04) \mathrm{kPa}$. Stability of gas exchange readings was assessed by tracking photosynthetic rate, stomatal conductance and total CV using the Li-6400's real-time graphing feature. Readings were logged when net photosynthesis and conductance appeared stable and total CV was less than 5\%, which was usually achieved within 1.0-1.5 min of placing leaves in the chamber. Average midday photosynthesis was calculated for each tree as the mean of morning and afternoon measurements. 


\subsubsection{Leaf Water Potential}

Mid-day leaf water potential $\left(\Psi_{\mathrm{w}}\right)$ was measured on trees of both species at both sites using a portable pressure chamber (Model 600, PMS Instrument Co. Albany, OR, USA) on three dates in 2014 (Old Town: 10 July, 8 Aug, 29 Sept; Downtown: 9 July, 6 Aug, 9 Sept) and four (Old town: 9 June, 8 July, 12 Aug, 10 Sept) or five (Downtown: 28 May, 24 June, 6 July, 6 Aug, 1 Sep) dates in 2015. Shoots were clipped from each tree using hand pruners or a pole pruner and a leaf was immediately removed for $\Psi_{\mathrm{w}}$ measurements. Weather conditions for dates on which $\Psi_{\mathrm{w}}$ was measured are presented in Table 2.

Table 2. Maximum daily temperature, total solar radiation and rainfall one week prior to leaf water potential measurements for street trees in Lansing, MI, USA in 2014 and 2015.

\begin{tabular}{ccccc}
\hline Location & Date & $\begin{array}{c}\text { Maximum Daily } \\
\text { Temperature }\left({ }^{\circ} \mathbf{C}\right)\end{array}$ & $\begin{array}{c}\text { Total Solar } \\
\text { Radiation (MJ) }\end{array}$ & $\begin{array}{c}\text { Rainfall 7 days } \\
\text { Prior (mm) }\end{array}$ \\
\hline Downtown & 9 July 2014 & 22.9 & 19.7 & 36.8 \\
& 6 Aug 2014 & 25.9 & 20.1 & 30.0 \\
& 9 Sept 2014 & 25.3 & 16.2 & 15.2 \\
& 28 May 2015 & 26.6 & 25.6 & 13.5 \\
& 24 June 2015 & 25.7 & 25.3 & 5.8 \\
6 July 2015 & 28.1 & 22.4 & 18.5 \\
& 6 Aug 2015 & 24.9 & 19.2 & 3.6 \\
1 Sept 2015 & 30.4 & 22.5 & 36.8 \\
& 10 Jul 2014 & 24.5 & 19.2 & 29.0 \\
& 8 Aug 2014 & 25.1 & 15.0 & 0.0 \\
& 29 Sept 2014 & 25.0 & 22.4 & 9.4 \\
& 9 June 2015 & 24.7 & 14.2 & 24.9 \\
& 8 July 2015 & 18.8 & 22.0 & 60.2 \\
& 12 Aug 2015 & 25.3 & 16.9 & 68.3 \\
\hline
\end{tabular}

Note: Source: Michigan State University Enviroweather automated station at Hancock Turf Research Center, Approx. $7 \mathrm{~km}$ from study sites. https://enviroweather.msu.edu/.

\subsubsection{Leaf Morphology and Shoot Growth}

Leaf size and specific leaf mass were measured on leaf samples collected from each tree in September 2014 and 2015. Shoots were clipped from each tree using a pole pruner and 20 leaves were collected from each tree. Leaf area of the sample was estimated by passing all leaves through a leaf area meter (Li-3000, Li-Cor, Inc. Lincoln, NE USA). After determining leaf area, we dried and weighed the leaves. Leaf size $\left(\mathrm{cm}^{2}\right.$ leaf $\left.{ }^{-1}\right)$ was calculated by dividing the total sample leaf area by the number of leaves in the sample. Specific leaf mass $\left(\mathrm{g} \mathrm{cm}^{-2}\right)$ was calculated by dividing the dry weight of each leaf sample by its leaf area. We collected three shoots from each Callery pear tree in fall 2015 that included the current year's growth plus the previous three years growth. Shoot growth from 2012 (pre-treatment), 2013 (treatment year), and 2014 and 2015 growing seasons was estimated by measuring the distance between the base of the terminal bud or bud-scale scar and the bud scale scar of the previous year. Shoot growth increments on the honeylocust trees were too small to reliably estimate annual shoot growth.

\subsubsection{Analysis}

The effect of treatment, species, and treatment $\times$ species interaction were determined for leaf morphology variables and SPAD index, by analysis of variance using SAS GLM (SAS ver. 9.4, SAS Institute, Inc. Cary, NC, USA). The effect of treatment and, where appropriate, species and treatment $\times$ species interaction, were determined by repeated measures analysis of variance for gas exchange and water potential data. Normality of residuals was tested by the Shapiro-Wilk test. When necessary, residuals were normalized by transforming response data using square root or arcsine (square root) transformations. 


\section{Results}

\subsection{SPAD Chlorophyll Index}

Application of paclobutrazol increased $(p<0.01)$ SPAD chlorophyll index for trees of both species in both years (Figure 2). For pear trees treated with paclobutrazol, mean SPAD index increased by 3 SPAD units (8\%) in 2014 and 5 SPAD units (13\%) in 2015, compared to untreated control trees. For honeylocust trees, paclobutrazol application increased SPAD index by 3 SPAD units (7\%) and 8 SPAD units (15\%) in 2014 and 2015, respectively. Species affected $(p<0.01)$ SPAD values as SPAD index of honeylocust trees was 4 SPAD units higher than pear trees in both years. The interaction of species and paclobutrazol was not significant $(p>0.05)$, indicating the relative response of SPAD to paclobutrazol was similar between species.
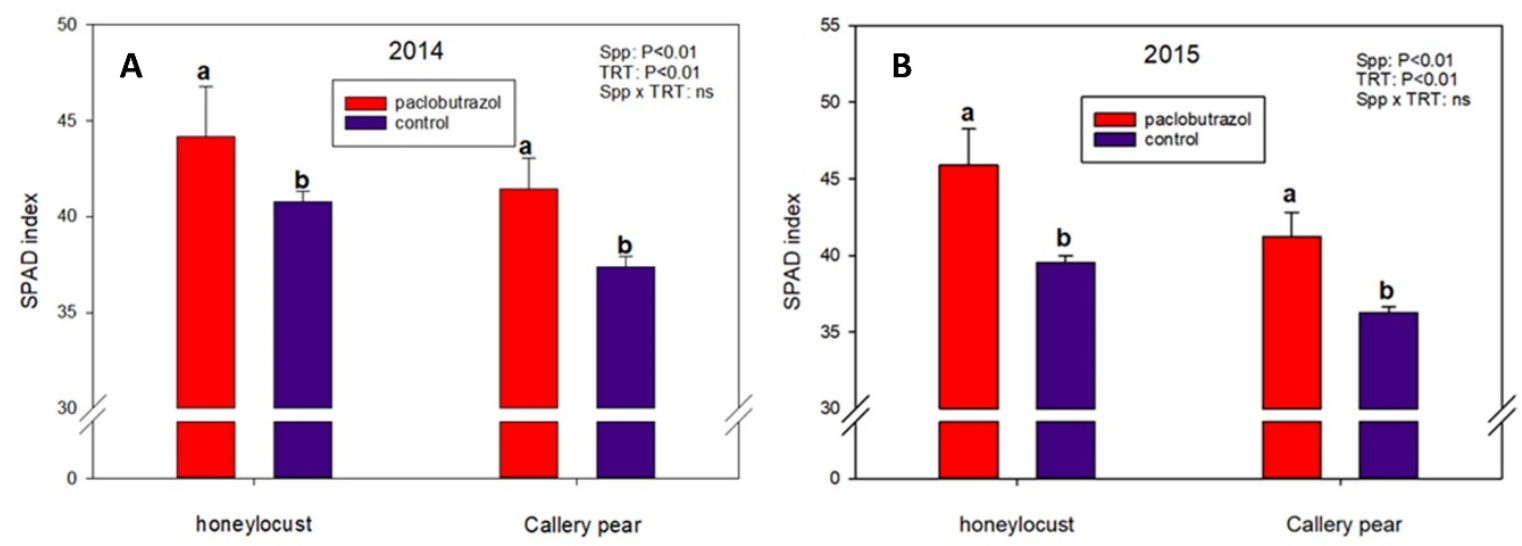

Figure 2. Mean SPAD chlorophyll index of honeylocust and Callery pear street trees in Lansing, MI, USA in 2014 (A) and 2015 (B). Trees were treated with paclobutrazol in 2013 or not treated (control). Error bars indicate standard error of the mean. Means within a species and year with the same letter are not different at $p=0.05$.

\subsection{Photosynthetic Gas Exchange}

On the Downtown site, application of paclobutrazol increased $(p<0.05)$ net photosynthesis and stomatal conductance on the July 2014 measurement date (Table 3). In August 2015, there was no difference in gas exchange rates between paclobutrazol-treated and untreated trees. On the other dates, net photosynthesis and conductance were higher for paclobutrazol-treated trees compared to untreated control trees but the differences were not statistically significant. Averaged across measurement dates, paclobutrazol application increased net photosynthesis by $11.5 \%$ and increased stomatal conductance by $14.2 \%$.

Table 3. Mean (std. err.) midday net photosynthesis and stomatal conductance of Callery pear trees in downtown Lansing, Michigan USA, on four dates in 2014 and 2015. Trees were treated with paclobutrazol (PBZ) in 2013 or not treated (control).

\begin{tabular}{|c|c|c|c|c|}
\hline \multirow[b]{2}{*}{ Date } & \multicolumn{2}{|c|}{ Net Photosynthesis $\left(\mu \mathrm{mol} \mathrm{m} \mathrm{m}^{-2} \mathrm{~s}^{-1}\right)$} & \multicolumn{2}{|c|}{ Stomatal Conductance $\left(\mathrm{mmol} \mathrm{m}^{-2} \mathrm{~s}^{-1}\right)$} \\
\hline & PBZ & Control & PBZ & Control \\
\hline 9 Jul 2014 & 17.4a (0.6) & $14.9 \mathrm{~b}(0.7)$ & $279.5 a(11.1)$ & $217.3 b(16.2)$ \\
\hline 6 Aug 2014 & $12.8 \mathrm{a}(0.8)$ & $11.5 a(0.6)$ & $235.6 \mathrm{a}(24.2)$ & 215.7a (17.8) \\
\hline 6 Aug 2015 & $7.1 \mathrm{a}(0.6)$ & $7.1 \mathrm{a}(0.4)$ & $124.2 \mathrm{a}(13.4)$ & 127.4a (11.5) \\
\hline 1 Sept 2015 & $9.4 \mathrm{a}(0.7)$ & $8.4 \mathrm{a}(0.5)$ & 213.1a (18.9) & 185.7a (13.7) \\
\hline
\end{tabular}

Note: means within row for a given variable followed by the same letter are not different at $p=0.05(\mathrm{n}=19)$. 


\subsection{Leaf Water Potential}

Paclobutrazol increased $(p<0.05)$ midday $\Psi_{\mathrm{w}}$ of honeylocust trees on the Downtown site. This effect was particularly apparent in 2015 when $\Psi_{\mathrm{w}}$ was generally lower than in 2014, reaching a minimum of -2.0 MPa on the Downtown site in September 2015 (Figure 3).
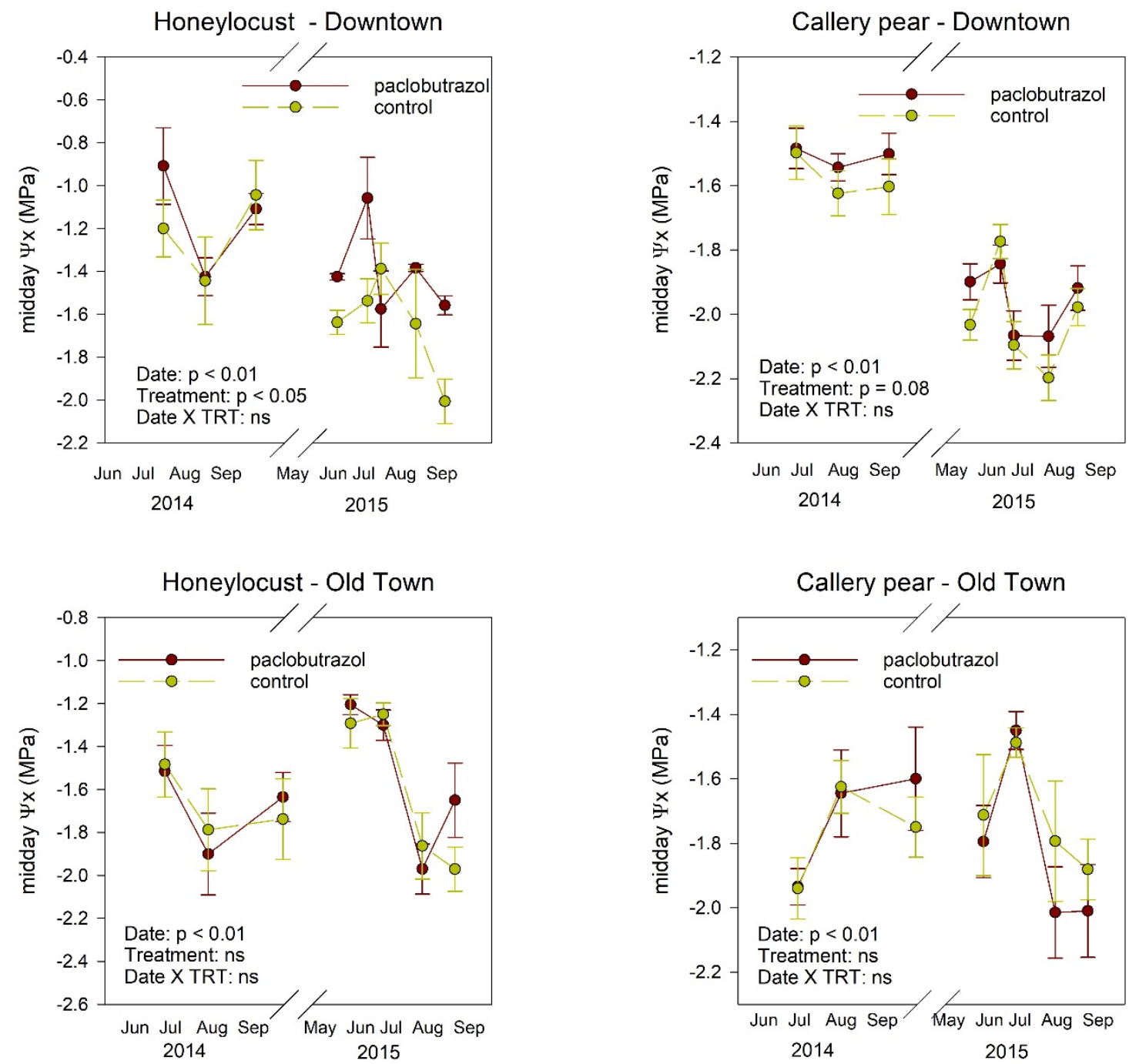

Figure 3. Mean midday leaf water potential $(\Psi w)$ of honeylocust and Callery pear trees at two locations in Lansing, MI USA in 2014 and 2015. Trees were treated with paclobutrazol in 2013 (paclobutrazol) or not treated (control). Error bars indicate standard error of the mean.

\subsection{Leaf Morphology and Shoot Growth}

Leaf area response to paclobutrazol varied between species $(\operatorname{spp} \times \operatorname{trt} ; p<0.05)$ (Figure 4). Application of paclobutrazol reduced $(p<0.01)$ mean leaf size of Callery pear trees in both 2014 and 2015 (Figure 4 top). In contrast, leaf size of honeylocust trees was unaffected by paclobutrazol application (Figure 4 bottom). Specific leaf mass was higher for Callery pear trees $\left(140.7 \mathrm{~g} \mathrm{~m}^{-2}\right)$ than for honeylocust trees $\left(56.4 \mathrm{~g} \mathrm{~m}^{-2}\right)$ but was not affected $(p>0.05)$ by paclobutrazol application. Mean shoot growth of Callery pear trees was $12 \mathrm{~cm}$ in 2014 and $8 \mathrm{~cm}$ in 2015. There was no difference in shoot growth between the paclobutrazol-treated and untreated trees in 2012 (pretreatment), 2013 (treatment year), 2014 or 2015 (data not shown). 
Callery pear

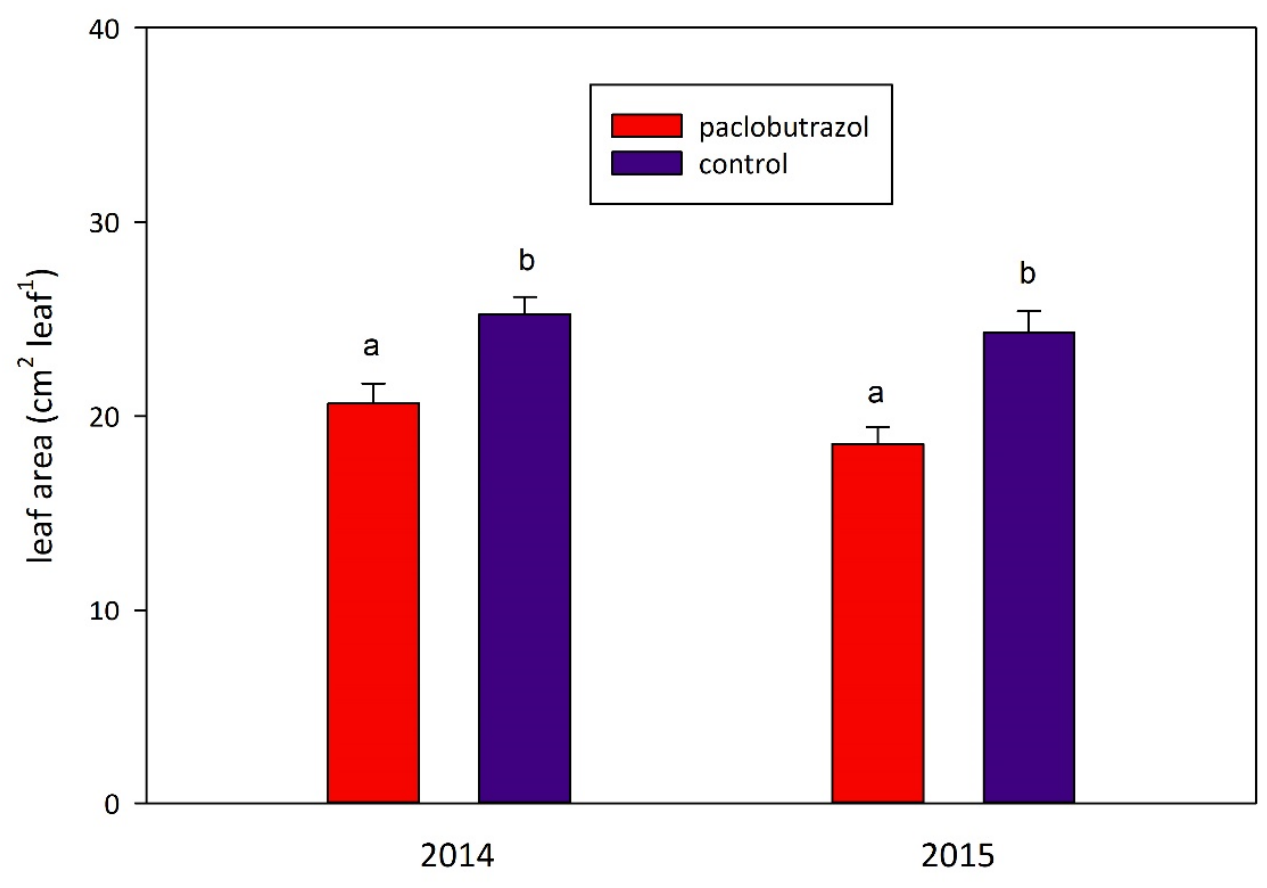

Honeylocust

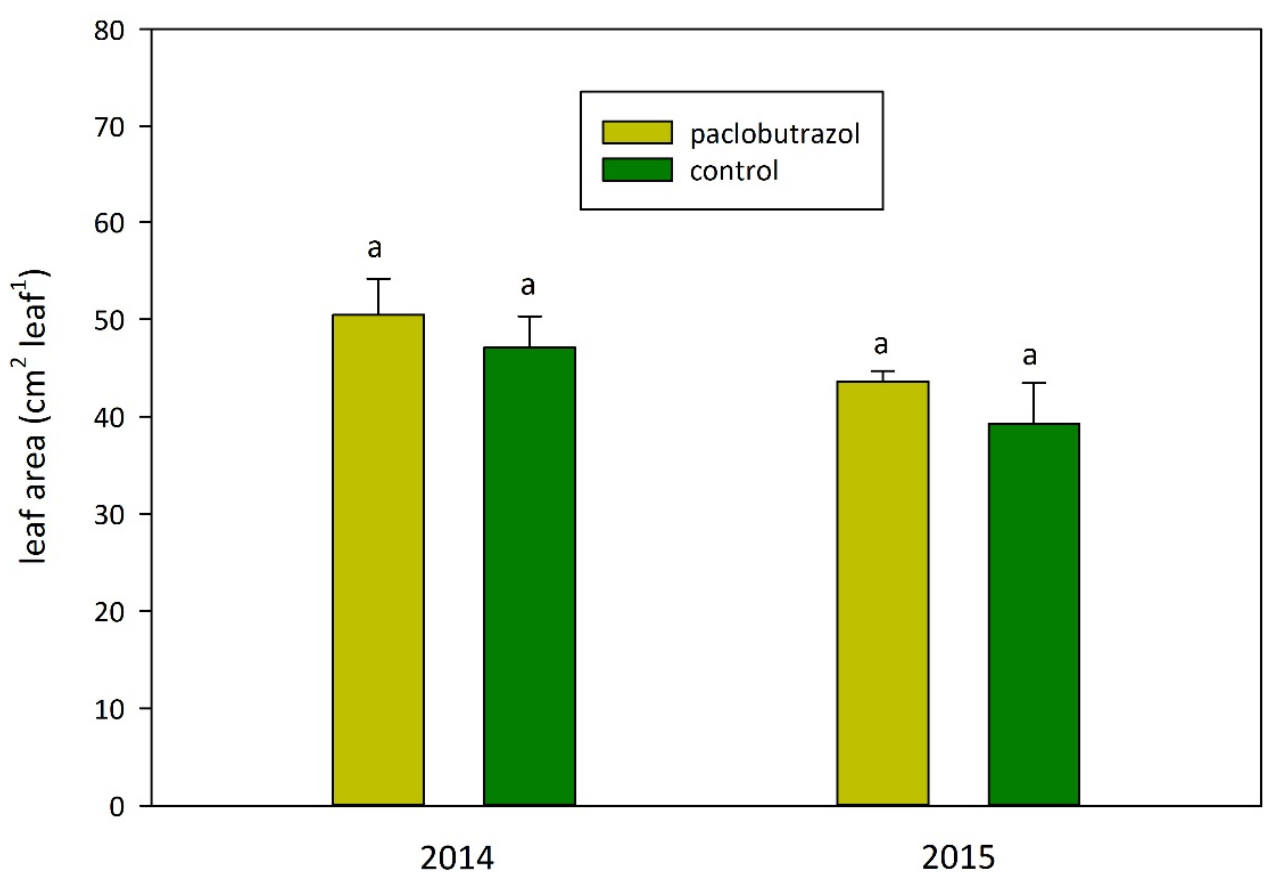

Figure 4. Mean leaf size of leaves of Callery pear (top) and honeylocust (bottom) trees in Lansing, MI USA in 2014 and 2015. Trees were treated with paclobutrazol in 2013 (paclobutrazol) or not treated (control). Error bars indicate standard error of the mean. Means within a species and year indicated by the same letter are not different at $p=0.05$. 


\section{Discussion}

In this study, we investigated the potential for application of paclobutrazol to mitigate environmental stress of trees in urban areas. Paclobutrazol can mitigate the impacts of urban stresses on trees directly by stimulating biochemical responses including synthesis of chlorophyll, secondary pigments, and other molecules to protect against oxidative stresses $[6,23,24]$. In addition, paclobutrazol inhibits shoot and leaf growth relative to root growth $[7,36]$, which can mitigate stress by reducing tree water loss and improving tree water status (increased leaf water potential) $[10,14]$.

The response of urban trees to application in situ were not as definitive as many studies of paclobutrazol on trees grown in containers or under more controlled conditions. This is not surprising given the heterogeneity of the urban environment. Nevertheless, we observed evidence of both direct and indirect (growth mediated) effects of paclobutrazol on stress responses of the trees on the two sites. The most consistent response of trees to paclobutrazol was increased SPAD chlorophyll index, which increased for trees of both species in both years. For the honeylocust trees, the increase in SPAD following paclobutrazol application could be the result of a stimulation of chlorophyll production, given that leaf size of these trees was not affected by paclobutrazol. For Callery pear trees, increased SPAD could be the result of a direct stimulation of chlorophyll production or a concentration effect-similar amount of chlorophyll in a smaller leaf-as the increase in SPAD index coincided with reduced leaf size. SPAD index can also be affected by leaf thickness [37], which can increase following paclobutrazol application [25].

Increases in net photosynthesis of Callery pear following treatment with paclobutrazol may be related to improved foliar nutrition, improved midday water potentials or both. Although we did not measure foliar nutrient concentrations directly, the consistent increases in SPAD chlorophyll content in both years, suggest that foliar nitrogen concentrations, which are highly correlated with SPAD, were higher following paclobutrazol application [23,38]. Given that net photosynthesis is strongly linked to foliar $\mathrm{N}$ in deciduous trees [39], this would lead to higher photosynthetic capacity. Increases in photosynthesis and conductance could also be related to improved plant water relations, at least on the Downtown site. Paclobutrazol could improve tree water status by increasing fine root production [7] or by reducing overall tree water use through reduced leaf area $[10,11,40]$, or both.

The lack of a shoot growth response in this study is somewhat surprising as this is the most common response of trees to paclobutrazol and is widely reported in the literature [1]. It is unlikely that the trees did not take up applied paclobutrazol. The application rates and methods used followed labeled guidelines for the product and the root systems of treated trees were confined to sidewalk tree pits. Moreover, the consistent effect of paclobutrazol on SPAD in this study indicates the trees took up and responded to paclobutrazol. While most studies report reductions in shoot growth in response to application of paclobutrazol, some studies report no effect or occasionally stimulation of shoot growth in response to paclobutrazol [41,42].

Watson et al. $[43,44]$ suggest that managing trees on urban sites requires an integration of multiple approaches (e.g., mulch, irrigation, aeration, prevention of compaction) to overcome site and soil limitations. The results of the present study indicate that plant growth regulators (PGR's) such as paclobutrazolmay provide arborists with an additional tool to manage trees in stressful locations. We observed consistent increases in SPAD chlorophyll index, suggesting improved tree nutrition and modest but measurable improvements in plant water relations and photosynthetic gas exchange. Nonetheless, PGR's are not a panacea or replacement of sound overall tree health management but should be viewed as an additional tool in the arborist's toolbox.

Lastly, this study illustrates the challenges and pitfalls of physiology research in street tree populations. In addition to variable soils and other environmental conditions, management of the trees varied. All trees were in or near an active downtown business zone with retail shops, restaurants and other businesses. Some study trees were mulched and tended by adjacent businesses and, in some cases, occasionally watered. "By-stander interference" is not unheard of in street tree studies. Watson and Himelick [8] reported over one-third of trees in study of pin oak chlorosis were treated by 
residents even though the residents had agreed previously not to treat the trees. In the current study, four Callery pear trees were removed during the trial for utility construction. These challenges should not preclude study of urban trees but point out the need for increased replication, robust experimental designs, and good cooperation and communication with community partners.

\section{Conclusions}

A growing body of literature has demonstrated that paclobutrazol application can result in a range of morpho-physiological responses that may mitigate impacts of stresses on trees in urban areas. In this trial, the paclobutrazol application consistently increased foliar SPAD index and, in some instances, increased photosynthetic rates and leaf water potential, suggesting that pacolbutrazolmay be useful as part of an overall management program for urban trees.

Author Contributions: Study conceptualization, design, data analysis, writing-original draft B.C.; Data entry and presentation graphics, D.E.-S.; Study installation, data collection, writing-review and editing D.E.-S. and B.C. Both authors have read and agreed to the published version of the manuscript.

Acknowledgments: We thank Devin Berry and Nicole Rowley for assistance with field data collection. We thank Brad Rowe and two anonymous reviewers for helpful reviews of a previous version of this manuscript. Sam Drahm, Rainbow Treecare Scientific Advancements, provided technical assistance and assisted with treatment applications. Rainbow Treecare Scientific Advancements provided product (Cambistat). This research was supported by USDA National Institute of Food and Agriculture, Hatch Project MICL02403 through Michigan State University AgBioResearch.

Conflicts of Interest: The authors declare no conflict of interest.

\section{References}

1. McLoughlin, K.T. Tree Growth Regulators for Management of Trees in Electric Utility Rights-of-Way: A Literature and Current Status Review; EPRI: Palo Alto, CA, USA, 2000; p. 90.

2. Davis, T.D.; Curry, E.A.; Steffens, G.L. Chemical regulation of vegetative growth. Crit. Rev. Plant Sci. 1991, 10, 151-188. [CrossRef]

3. Bai, S.; Chaney, W.; Qi, Y. Response of cambial and shoot growth in trees treated with paclobutrazol. J. Arboric. 2004, 30, 137-145.

4. Mathews, S. Use of a Tree Growth Regulator to Manage Vegetation near Overhead Power Lines. Master's Thesis, Oklahoma State University, Stillwater, OK, USA, 2009.

5. Qi, Y.; Self, S.; Bai, S.; Ferchaud, V.; Chin, K.L.; Chaney, W.R. Effect of paclobutrozol tree growth regulator on two tree species. In Proceedings of the 41st Annual Meeting of the Plant Growth Regulation Society of America \& Japanese Society for the Chemical Regulation of Plants, San Francisco, CA, USA, 13-17 July 2014; Volume 41, p. 6.

6. Soumya, P.R.; Kumar, P.; Pal, M. Paclobutrazol: A novel plant growth regulator and multi-stress ameliorant. Indian J. Plant Physiol. 2017, 22, 267-278. [CrossRef]

7. Watson, G.W. Tree root system enhancement with paclobutrazol. In The Supporting Roots of Trees and Woody Plants: Form, Function and Physiology; Stokes, A., Ed.; Development in Plant and Soil Sciences; Springer: Dordrecht, The Netherlands, 2000; Volume 87, pp. 131-135.

8. Watson, G.W.; Himelick, E.B. Effects of soil pH, root density, and tree growth regulator treatments on pin oak chlorosis. Arboric. Urban For. 2004, 30, 172.

9. Chorbadjian, R.A.; Bonello, P.; Herms, D.A. Effect of the growth regulator paclobutrazol and fertilization on defensive chemistry and herbivore resistance of Austrian pine (Pinus nigra) and paper birch (Betula papyrifera). Arboric. Urban For. 2011, 37, 278.

10. Navarro, A.; Sanchez-Blanco, M.J.; Bañon, S. Influence of paclobutrazol on water consumption and plant performance of Arbutus unedo seedlings. Sci. Hortic. 2007, 111, 133-139. [CrossRef]

11. Navarro, A.; Sanchez-Blanco, M.J.; Morte, A.; Banon, S. The influence of mycorrhizal inoculation and paclobutrazol on water and nutritional status of Arbutus unedo L. Environ. Exp. Bot. 2009, 66, 362-371. [CrossRef]

12. Ruter, J.M.; Martin, C.A. Effects of contrasting climate and paclobutrazol on the growth and water use of two container-grown landscape plants. J. Environ. Hortic. 1994, 12, 27-32. 
13. Martin, C.A.; Sharp, W.P.; Ruter, J.M.; Garcia, R.L. Alterations in leaf morphology of two landscape shrubs in response to disparate climate and paclobutrazol. HortScience 1994, 29, 1321-1325. [CrossRef]

14. Zhu, L.H.; van de Peppel, A.; Li, X.Y.; Welander, M. Changes of leaf water potential and endogenous cytokinins in young apple trees treated with or without paclobutrazol under drought conditions. Sci. Hortic. 2004, 99, 133-141. [CrossRef]

15. Ju, S.; Xu, D.; Zhan, C.; Ji, L.; Yin, T.; Li, Z.; Lu, Z. Influence of Paclobutrazol on the Growth and Photosynthesis of Sequoia sempervirens Seedlings. J. Hortic. Res. 2019, 27, 21-30. [CrossRef]

16. Martínez-Trinidad, T.; Watson, W.T.; Book, R.K. Impact of paclobutrazol on root-pruned live oak. HortTechnology 2011, 21, 46-50. [CrossRef]

17. Huang, W.D.; Shen, T.; Han, Z.H.; Liu, S. Influence of paclobutrazol on photosynthesis rate and dry matter partitioning in the apple tree. J. Plant Nutr. 1995, 18, 901-910. [CrossRef]

18. Qi, Y.; Bai, S.; Chaney, W.R.; Drye, K. Effects of Paclobutrazol on Leaf Optical Properties of Sweetgum and Cherrybark Oak. In Proceedings of the 27th Annual Plant Growth Regulation Society of America, Kailua-Kona, HI, USA, 30 July-3 August 2000; Volume 27, pp. 260-265.

19. Qi, Y.; Knighten, T.; Chaney, W.R. Leaf Physiology and Anatomy of Two Urban Tree Species as Affected by Paclobutrazol Tree Growth Regulator. In Proceedings of the 29th Annual Plant Growth Regulation Society of America, Halifax, NS, Canada, 28 July-1 August 2002; Volume 29, pp. 123-128.

20. Mohan, R.; Kaur, T.; Bhat, H.A.; Khajuria, M.; Pal, S.; Vyas, D. Paclobutrazol Induces Photochemical Efficiency in Mulberry (Morus alba L.) Under Water Stress and Affects Leaf Yield Without Influencing Biotic Interactions. J. Plant Growth Regul. 2019, 1-11. [CrossRef]

21. Mohan, R.; Vyas, D.; Bhat, H.A.; Kaur, T.D.; Dhar, A. Exploring possibilities of induction of water stress tolerance in mulberry in rainfed condition by application of paclobutrazol. J. Glob. Biosci. 2015, 4, 3301-3310.

22. Singh, S.K.; Pandey, A.K.; Singh, P. Gaseous exchange, biochemical parameters and yield as affected by application techniques and doses of Paclobutrazol in litchi tree. Hortic. Soc. India 2019, 76, 265-272. [CrossRef]

23. Percival, G.C.; AlBalushi, A.M.S. Paclobutrazol-induced drought tolerance in containerized English and evergreen oak. Arboric. Urban For. 2007, 33, 397.

24. Srivastav, M.; Kishor, A.; Dahuja, A.; Sharma, R.R. Effect of paclobutrazol and salinity on ion leakage, proline content and activities of antioxidant enzymes in mango (Mangifera indica L.). Sci. Hortic. 2010, 125, 785-788. [CrossRef]

25. Qi, Y.; Ferchaud, V.; Chin, K.; Xiao, Y. Leaf anatomical changes induced by paclobutrazol tree growth regulator in Cherrybark Oak. Microsc. Microanal. 2016, 22, 1202-1203. [CrossRef]

26. De Lacy, P.; Shackleton, C.M. The comparative growth rates of indigenous street and garden trees in Grahamstown, South Africa. S. Afr. J. Bot. 2014, 92, 94-96. [CrossRef]

27. Quigley, M.F. Street trees and rural conspecifics: Will long-lived trees reach full size in urban conditions? Urban Ecosyst. 2004, 7, 29-39. [CrossRef]

28. Craul, P.J. A description of urban soils and their desired characteristics. J. Arboric. 1985, 11, 330-339.

29. Kjelgren, R.K.; Clark, J.R. Microclimates and tree growth in three urban spaces. J. Environ. Hortic. 1992, 10, 139-145.

30. De Kimpe, C.R.; Morel, J.L. Urban soil management: A growing concern. Soil Sci. 2000, 165, 31-40. [CrossRef]

31. Lindsey, P.; Bassuk, N. Specifying soil volumes to meet the water needs of mature urban street trees and trees in containers. J. Arboric. 1991, 17, 141-149.

32. Cregg, B.M. Plant moisture stress of green ash trees in contrasting urban sites. J. Arboric. 1995, 21, $271-276$.

33. Whitlow, T.H.; Bassuk, N.L.; Reichert, D.L. A 3-year study of water relations of urban street trees. J. Appl. Ecol. 1992, 29, 436-450. [CrossRef]

34. Cregg, B.M.; Dix, M.E. Tree moisture stress and insect damage in urban areas in relation to heat island effects. J. Arboric. 2001, 27, 8-17.

35. Watson, G.W. Soil applied paclobutrazol affects root growth, shoot growth, and water potential of American elm seedlings. J. Environ. Hortic. 2001, 19, 119-122.

36. Tanis, S.R.; McCullough, D.G.; Cregg, B.M. Effects of paclobutrazol and fertilizer on the physiology, growth and biomass allocation of three Fraxinus species. Urban For. Urban Green. 2015, 14, 590-598. [CrossRef]

37. Marenco, R.A.; Antezana-Vera, S.A.; Nascimento, H.C.S. Relationship between specific leaf area, leaf thickness, leaf water content and SPAD-502 readings in six Amazonian tree species. Photosynthetica 2009, 47, 184-190. [CrossRef] 
38. Chang, S.X.; Robison, D.J. Nondestructive and rapid estimation of hardwood foliar nitrogen status using the SPAD-502 chlorophyll meter. For. Ecol. Manag. 2003, 181, 331-338. [CrossRef]

39. Reich, P.B.; Walters, M.B.; Kloeppel, B.D.; Ellsworth, D.S. Different photosynthesis-nitrogen relations in deciduous hardwood and evergreen coniferous tree species. Oecologia 1995, 104, 24-30. [CrossRef] [PubMed]

40. Fernandez, J.A.; Balenzategui, L.; Banon, S.; Franco, J.A. Induction of drought tolerance by paclobutrazol and irrigation deficit in Phillyrea angustifolia during the nursery period. Sci. Hortic. 2006, 107, 277-283. [CrossRef]

41. Estabrooks, E.N. Paclobutrazol sprays reduce vegetative growth and increase fruit production in young McIntosh apple trees. Can. J. Plant Sci. 1993, 73, 1127-1135. [CrossRef]

42. Tromp, J. Growth and flower-bud formation in apple as affected by paclobutrazol, daminozide and tree orientation in combination with various gibberellins. J. Hortic. Sci. 1987, 62, 433-440. [CrossRef]

43. Watson, G.W.; Hewitt, A.M.; Custic, M.; Lo, M. The management of tree root systems in urban and suburban settings: A review of soil influence on root growth. Arboric. Urban For. 2014, 40, 193-217.

44. Watson, G.W.; Hewitt, A.M.; Custic, M.; Lo, M. The management of tree root systems in urban and suburban settings II: A review of strategies to mitigate human impacts. Arboric. Urban For. 2014, 40, $249-271$.

(C) 2020 by the authors. Licensee MDPI, Basel, Switzerland. This article is an open access article distributed under the terms and conditions of the Creative Commons Attribution (CC BY) license (http://creativecommons.org/licenses/by/4.0/). 